\title{
DINAMIKA KELIMPAHAN BENIH LOBSTER (Panulirus spp.) DI PERAIRAN TELUK GERUPUK, NUSA TENGGARA BARAT: TANTANGAN PENGEMBANGAN TEKNOLOGI BUDIDAYA LOBSTER
}

\author{
Erlania, I Nyoman Radiarta, dan Ketut Sugama \\ Pusat Penelitian dan Pengembangan Perikanan Budidaya \\ Jl. Ragunan 20, Pasar Minggu, Jakarta Selatan 12540 \\ E-mail: erlania_elleen@yahoo.com
}

(Naskah diterima: 26 September 2014; Revisi final: 4 November 2014;

Disetujui publikasi: 10 November 2014)

\begin{abstract}
ABSTRAK
Aktivitas budidaya pembesaran lobster masih mengandalkan benih hasil tangkapan dari alam. Penelitian ini bertujuan untuk melakukan observasi kelimpahan benih lobster, Panulirus spp. di perairan Teluk Gerupuk, Lombok Tengah, Nusa Tenggara Barat, terkait dengan fluktuasi kualitas perairan secara spasial dan temporal. Data yang dikumpulkan mencakup kondisi kualitas perairan, kelimpahan benih lobster, dan total benih lobster hasil tangkapan di Teluk Gerupuk. Sebanyak sepuluh stasiun pengamatan kelimpahan lobster dan kualitas perairan disebar secara merata di lokasi penelitian. Pengamatan kelimpahan benih lobster menggunakan kolektor benih lobster yang dikenal dengan 'pocong', sedangkan data total tangkapan benih lobster diperoleh dari pengumpul di lokasi penelitian. Hasil penelitian menunjukkan bahwa sebaran kelimpahan benih lobster tertinggi ditemukan di perairan sekitar Desa Gerupuk dan Desa Bumbang, yaitu berkisar 22-101 ekor/stasiun selama masa penelitian. Lokasi tersebut memiliki karakteristik perairan yang relatif terlindung, dangkal, kekeruhan tinggi, dan dasar perairan pasir berlumpur. Secara temporal, puncak kelimpahan benih lobster tertinggi terjadi pada bulan Juni-Juli yaitu antar 83-142 ekor/bulan selama masa penelitian, dan data kelimpahan tersebut menunjukkan pola yang relatif sama dengan data hasil tangkapan benih oleh masyarakat. Saat ini, dukungan pengembangan teknologi budidaya lobster sangat diperlukan, khususnya teknologi pembesaran untuk meningkatkan nilai ekonomis benih lobster hasil tangkapan, dan teknologi pembenihan untuk menjaga ketersediaan benih lobster di alam dan mendukung budidaya lobster secara berkelanjutan.
\end{abstract}

KATA KUNCI: benih lobster, Panulirus spp., kelimpahan, budidaya, Teluk Gerupuk

ABSTRACT: Dynamics of lobster (Panulirus spp.) seeds abundance in Gerupuk Bay, West Nusa Tenggara: A challenge for lobster aquaculture technology development. By: Erlania, I Nyoman Radiarta, and Ketut Sugama

Lobster culture activities have relied on capturing of natural seed. This study was aimed to observe lobster seeds abundance in Gerupuk Bay, Central Lombok, West Nusa Tenggara, related to spatial and temporal fluctuation of water quality condition. Data were used in this study including water quality, lobster seeds abundance, and total catch of lobster seeds from Gerupuk Bay. A total of ten sampling stations for lobster abundance and water quality observation was distributed evenly in Gerupuk Bay. Lobster seeds abundance was collected by using seed collectors device called 


\begin{abstract}
'pocong', and total catch of lobster seeds data was recorded from seeds buyer who collected the seeds from farmers. The results showed that the highest lobster seeds abundance was found in Gerupuk and Bumbang Waters, ranged about 22-101 seeds/ station during observation period. These areas had the habitat characteristic relatively shallow, turbid, and sheltered waters with silted area. The temporal charecteristic was indicated that June-July had the highest of lobster seeds abundance, acounted about 83-142 seeds/month during observation period. This temporal trend has similar pattern with total catch of lobster seeds by farmers around Gerupuk Bay. Nowadays, lobster aquaculture technology is reguired, in particular grow-out technology to increase economic value of capture lobster seeds, and also hatching technology to maintain natural lobster seeds availability as well as to support sustainable lobster aquaculture activities.
\end{abstract}

\title{
KEYWORDS: Iobster seeds, Panulirus spp., abundance, aquaculture, Gerupuk Bay
}

\section{PENDAHULUAN}

Aktivitas budidaya pembesaran lobster dengan benih yang bersumber dari penangkapan di alam telah berkembang sejak awal tahun 2000 di perairan Lombok, Nusa Tenggara Barat; salah satunya yaitu di perairan Teluk Gerupuk (Suastika et al., 2008; Priambodo \& Sarifin, 2008). Teluk Gerupuk merupakan salah satu dari tiga lokasi utama penghasil benih lobster di Pulau Lombok selain Teluk Awang dan Teluk Telong Elong (Priambodo \& Jaya, 2009). Pada awalnya, aktivitas penangkapan benih dan pembesaran lobster di Teluk Gerupuk merupakan aktivitas sampingan dari budidaya rumput laut dan ikan kerapu yang telah berlangsung sejak tahun 1990-an, namun selanjutnya berkembang sebagai aktivitas utama mata pencaharian para pembudidaya seiring dengan meningkatnya harga benih lobster, dan terjadinya penurunan produktivitas budidaya rumput laut di lokasi tersebut. Intensitas usaha penangkapan benih lobster oleh masyarakat di sekitar Teluk Gerupuk saat ini semakin meningkat. Keramba apung sebagai media penangkapan benih lobster yang dipasang di perairan tersebut jumlahnya juga semakin banyak, yang juga merupakan bentuk konversi mata pencaharian masyarakat dari pembudidaya rumput laut menjadi penangkap benih lobster. Pada awalnya keramba apung tersebut digunakan untuk budidaya ikan dan pembesaran lobster, namun saat ini beralih fungsi sebagai media untuk memasang kolektor lobster yang oleh masyarakat setempat dikenal dengan sebutan 'pocong.'

Jenis lobster yang umumnya ditemukan di perairan Teluk Gerupuk yaitu Panulirus homarus (lobster pasir) dan P. ornatus (lobster mutiara). Siklus hidup lobster terbagi menjadi beberapa tahapan, yaitu telur, larva phyllosoma (1,5-2,0 $\mathrm{mm}$ dengan badan transparan), larva puerulus $(1,5-2,0 \mathrm{~cm}$ dengan badan transparan), dan stadia yuwana ( $2-3 \mathrm{~cm}$ dengan badan sudah memiliki pigmen), fingerling (lobster muda berukuran $6-8 \mathrm{~cm}$ ), dan lobster dewasa (Suastika et al., 2008; Thao, 2012). Setiap stadia hidup lobster berasosiasi dengan kondisi ekologi yang spesifik dan memperlihatkan daya adaptasi yang nyata dari lobster. Larva phyllosoma mengapung pada permukaan air dan akan terbawa oleh gelombang, arus, dan angin; puerulus dapat berenang bebas dan berpindah ke daerah dangkal dan terlindung; yuwana hidup di sekitar area pantai yang terlindung oleh rumput laut dan karang di mana terdapat makanan dan dapat terhindar dari predator (Thao, 2012).

Arcenal (2004) menyatakan bahwa, terdapat berbagai kriteria yang menjadi persyaratan, baik secara teknis maupun biologis untuk dapat mengembangkan suatu spesies potensial melalui budidaya. Keberhasilan dan keberlanjutan usaha budidaya laut selain bergantung pada kondisi lingkungan, juga harus didukung oleh ketersediaan benih yang berkesinambungan. Benih yang digunakan pada kegiatan budidaya dapat berasal dari proses pembenihan maupun dari hasil tangkapan di alam. Budidaya lobster (Panulirus spp.) merupakan salah satu aktivitas budidaya laut yang masih sangat bergantung pada ketersediaan benih alam. Menurut Priambodo \& Jaya (2009), pada umumnya benih yang digunakan pada usaha pembesaran lobster di Indonesia merupakan hasil tangkapan dari alam. Jeffs \& Davis (2003) menyatakan bahwa prospek budidaya lobster Panulirus lebih besar dibandingkan dengan spesies lobster dari per- 
airan iklim sedang (temperate species), karena faktor ketersediaan benih alam yang lebih besar, dan laju pertumbuhannya yang lebih tinggi.

Terjadinya fenomena perubahan iklim global yang mengakibatkan fluktuasi kondisi iklim yang tidak dapat diprediksi akan memengaruhi fluktuasi kondisi perairan. Hal ini diduga juga dapat berdampak pada ketersediaan benih lobster di perairan. Thangaraja \& Radhakrishnan (2012) menyatakan bahwa parameter lingkungan merupakan faktor pembatas dari distribusi setiap spesies lobster. Setiap spesies memiliki habitat dengan karakteristik yang spesifik sesuai kebutuhannya terkait ketersediaan makanan, tempat berlindung, dan reproduksinya. Ketergantungan aktivitas budidaya terhadap benih lobster dari alam akan menjadi permasalahan tersendiri dalam perkembangan usaha pembesaran lobster. Penangkapan benih lobster yang berlangsung terus-menerus akan berakibat menurunnya stok benih di alam. Tingginya permintaan lobster secara ekonomis memang bersifat menguntungkan; namun penangkapan benih lobster dari alam tanpa memperhatikan aspek biologi dan habitatnya telah menyebabkan habisnya populasi lobster pada sebagian besar perairan, sebagai contoh di wilayah Barat Pulau Mindanao, Filipina
(Arcenal, 2004). Demikian juga dengan kondisi yang terjadi di perairan Teluk Gerupuk, Lombok. Oleh karena itu, perlu dilakukan pengamatan terhadap dinamika kelimpahan benih lobster di perairan, sehingga dapat dilakukan pengelolaan yang baik untuk menjaga keberlanjutan usaha budidaya lobster di masa yang akan datang.

Penelitian ini bertujuan untuk melakukan observasi kelimpahan benih lobster alam di perairan Teluk Gerupuk terkait dengan fluktuasi kondisi lingkungan perairan secara spasial dan temporal. Hasil dari penelitian ini diharapkan dapat memberikan informasi tentang dinamika kelimpahan benih lobster alam yang bermanfaat untuk mendukung pengelolaan dan ketersediaan benih bagi usaha budidaya pembesaran lobster di Indonesia.

\section{BAHAN DAN METODE}

Penelitian telah dilakukan di perairan Teluk Gerupuk Kabupaten Lombok Tengah Provinsi Nusa Tenggara Barat pada bulan April-September 2013 . Teluk Gerupuk terbentang pada posisi 8०54'-8'55'30'" Lintang Selatan dan $116^{\circ} 20^{\prime} 30^{\prime \prime}-116^{\circ} 23^{\prime}$ Bujur Timur (Gambar 1), dengan mulut teluk menghadap ke Selatan dan mendapat pengaruh langsung dari kondisi oseanografi perairan Samudera Hindia.

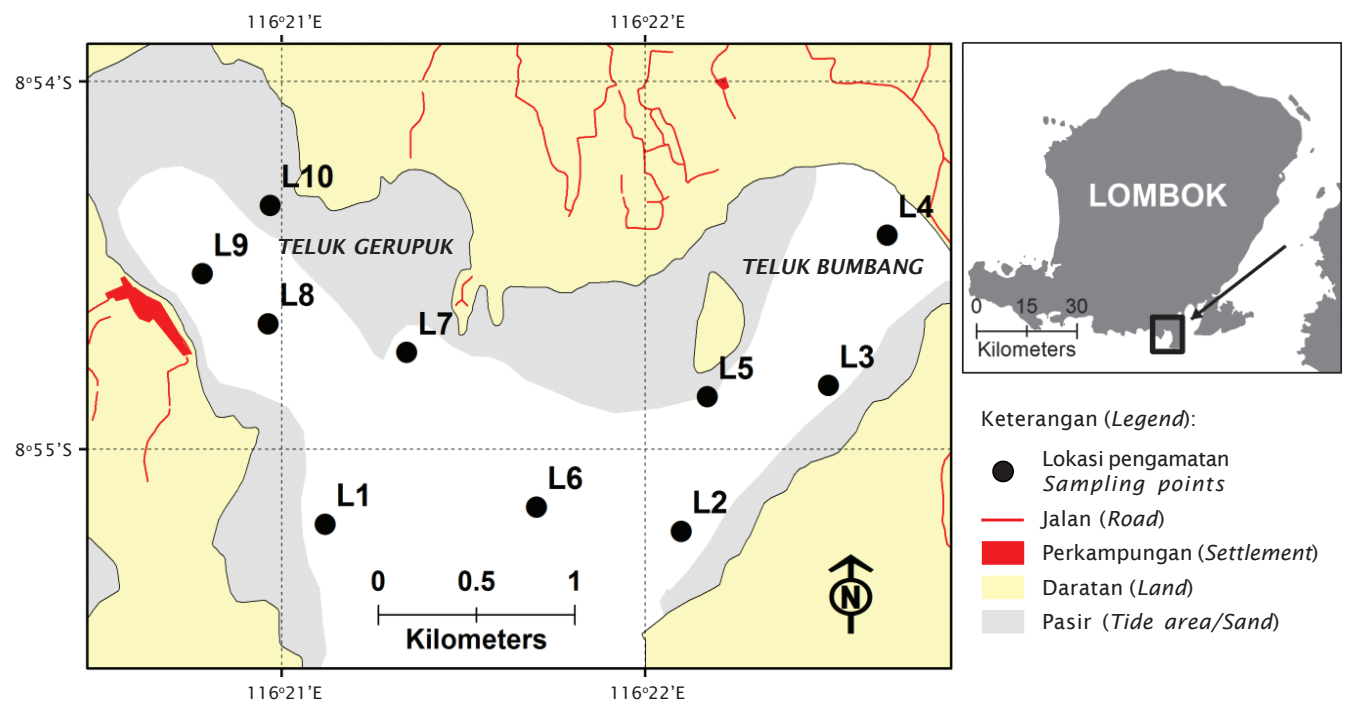

Gambar 1. Lokasi penelitian di Teluk Gerupuk, Lombok Tengah, Nusa Tenggara Barat (L1-L10 adalah stasiun pengumpulan benih lobster)

Figure 1. The study area in Gerupuk Bay, Central Lombok, West Nusa Tenggara (L1-L1O are the sampling stations for collecting lobster seeds) 
Data yang dikumpulkan terdiri atas kelimpahan benih lobster, kondisi kualitas perairan, dan total hasil tangkapan benih lobster di Teluk Gerupuk. Pengamatan kelimpahan benih lobster dilakukan dengan cara memasang alat kolektor benih lobster yang dikenal dengan nama "pocong" pada sepuluh stasiun pengamatan (Gambar 1). Pocong terbuat dari karung plastik yang salah satu ujungnya diikat dengan tali dan digantungkan pada bambu sepanjang $5 \mathrm{~m}$ yang diberi pelampung pada kedua ujungnya. Pocong digantungkan pada bambu dengan jarak sekitar $0,5 \mathrm{~m}$ dari dasar perairan. Pada setiap $5 \mathrm{~m}$ bambu terdapat sepuluh pocong yang digantung dengan jarak antar gantungan sekitar $50 \mathrm{~cm}$. Pada setiap stasiun dipasang satu bambu dengan sepuluh kolektor. Pengumpulan data kelimpahan lobster pada setiap stasiun pengamatan dilakukan setiap dua minggu dengan cara mengangkat kolektor dari dalam air untuk mengumpulkan benih lobster yang menempel di sela-sela pocong tersebut.

Jumlah benih lobster yang ditemukan setiap minggu pada setiap stasiun pengamatan dihitung untuk mengetahui sebaran dan fluktuasi kelimpahannya setiap bulan. Data benih yang dikoleksi merupakan jumlah dari sepuluh kolektor untuk setiap stasiun. Pengukuran parameter kualitas perairan dilakukan pada sepuluh stasiun pengamatan yang sama dengan stasiun pengamatan kelimpahan lobster (Gambar 1). Parameter kualitas air diukur secara in situ di lapangan menggunakan YSI Profesional+ yang meliputi: suhu, salinitas, DO, $\mathrm{pH}$, dan padatan terlarut total (total dissolved solid/TDS). Data total hasil tangkapan benih lobster di perairan Teluk Gerupuk dikumpulkan setiap bulan selama tahun 2013. Data tersebut dikoleksi dari pengumpul yang menerima benih lobster dari petani/penangkap benih.

Data yang terkumpul dianalisis dengan metode statistik. Data kelimpahan lobster pada setiap stasiun dan waktu pengamatan, serta data parameter kualitas perairan dianalisis secara deskriptif dan ditampilkan dalam bentuk grafik. Analisis klaster (cluster analysis) dengan metode single linkage method dilakukan terhadap sebaran parameter kualitas perairan untuk melihat karakteristik perairan antar stasiun dan waktu pengamatan terkait dinamika kelimpahan benih lobster secara spasial dan temporal. Analisis klaster dilakukan dengan menggunakan software Minitab Ver. 16.1 .

\section{HASIL DAN BAHASAN}

\section{Kondisi Kualitas Perairan}

Kondisi kualitas air sangat berperan terhadap keberadaan, pertumbuhan, reproduksi, dan migrasi benih lobster di suatu perairan. Variabilitas pertumbuhan dan perkembangan lobster umumnya berhubungan dengan heterogenitas lingkungan (Phillips, 2006). Nilai parameter kualitas perairan di Teluk Gerupuk tidak memiliki perbedaan yang cukup signifikan antar stasiun pengamatan, namun relatif berfluktuasi antar waktu pengamatan (Gambar 2). Suhu perairan pada bulan April berkisar antara $30,26^{\circ} \mathrm{C}-31,46^{\circ} \mathrm{C}$; relatif lebih tinggi dibandingkan bulan Mei-Juni $\left(28,50^{\circ} \mathrm{C}\right.$ $\left.29,86^{\circ} \mathrm{C}\right)$ dan bulan Juli-September $\left(26,77^{\circ} \mathrm{C}\right.$ $\left.27,95^{\circ} \mathrm{C}\right)$. Kondisi ini menggambarkan bahwa di perairan Teluk Gerupuk terdapat periodeperiode tertentu di mana tren suhu perairan mengalami perubahan yang cukup signifikan, dan hal ini dapat memengaruhi distribusi dan keberadaan biota, termasuk aktivitas budidayanya di perairan tersebut (Radiarta \& Rasidi, 2012; Radiarta et al., 2013). Perkembangan larva dan post larva dari lobster sangat sensitif terhadap perubahan suhu perairan (Phillips, 2006). Hasil studi Caputi (2010) menunjukkan bahwa tangkapan lobster Panulirus di perairan Barat Australia sangat dipengaruhi oleh beberapa parameter lingkungan penting, antara lain suhu perairan, Leeuwin current yaitu arus yang dipengaruhi oleh El Nino-Southern Oscillation cycle, dan angin musim Barat.

Perubahan suhu perairan akan memengaruhi proses fisika, kimia, dan biologi badan air, sehingga akan berpengaruh terhadap fluktuasi nilai parameter kualitas perairan lainnya termasuk parameter $\mathrm{DO}, \mathrm{pH}$, dan salinitas perairan (Effendi, 2003). Kandungan padatan terlarut (TDS) lebih banyak dipengaruhi oleh pelapukan batuan, limpasan daratan, dan aktivitas manusia (faktor antropogenik); dan nilai TDS yang tinggi akan menyebabkan kondisi perairan menjadi keruh dan menghambat penetrasi cahaya untuk masuk ke kolom perairan (Effendi, 2003). Intensitas cahaya secara signifikan sangat memengaruhi pertumbuhan dan perkembangan benih lobster, serta menentukan musim terjadinya siklus moulting pada lobster (Phillips, 2006). 

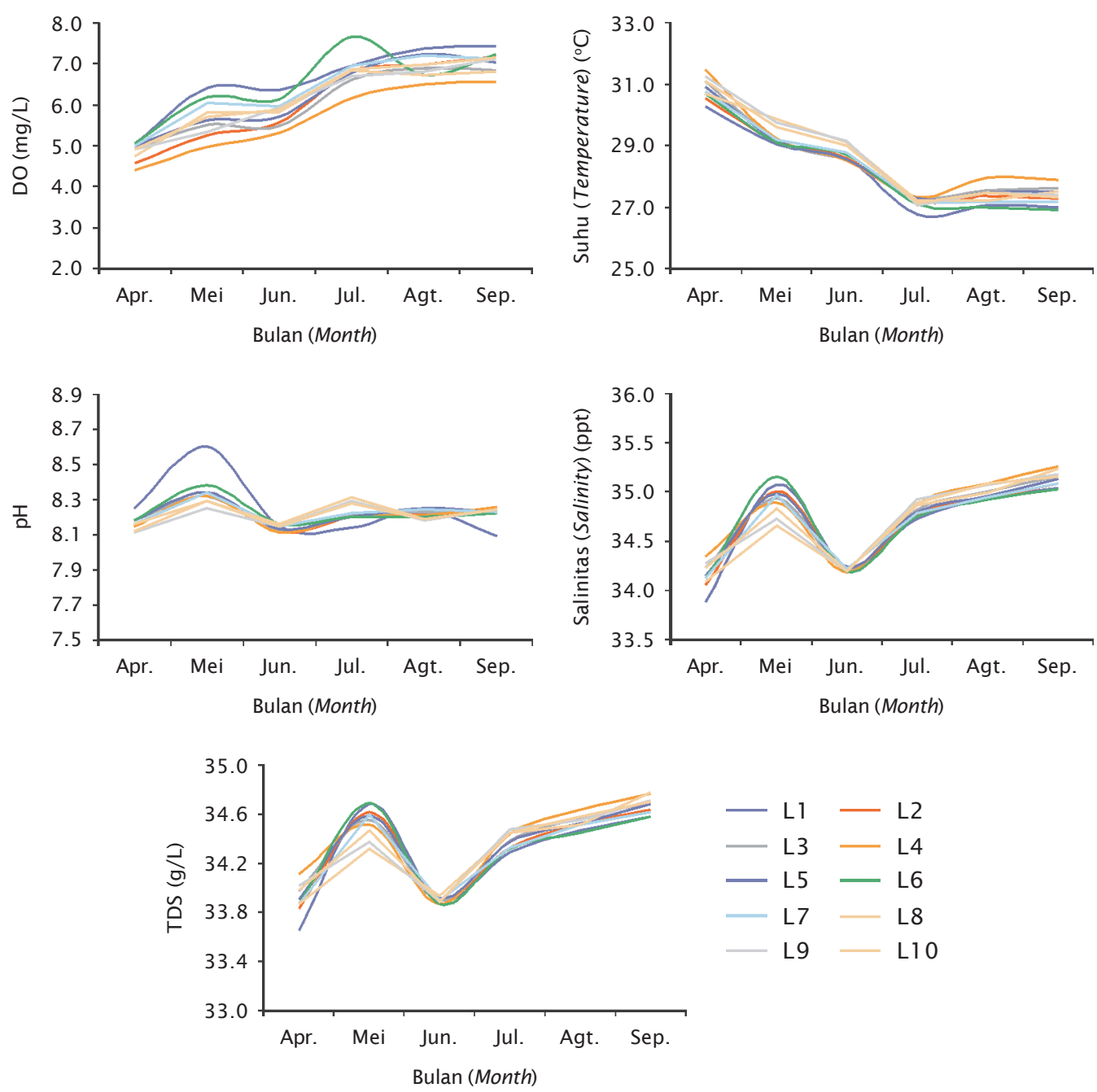

Gambar 2. Variasi kualitas perairan bulan April-September 2013 pada setiap stasiun dan waktu pengamatan di Teluk Gerupuk, Nusa Tenggara Barat

Figure 2. Temporal and spatial water quality variation from April-September 2013 at each observation stations in Gerupuk Bay, West Nusa Tenggara

\section{Distribusi Spasial Kelimpahan Benih Lobster}

Distribusi kelimpahan benih lobster pada sepuluh stasiun pengamatan di perairan Teluk Gerupuk diperlihatkan pada Gambar 3. Jumlah benih lobster yang diperoleh dari setiap kolektor yang dipasang menunjukkan adanya perbedaan distribusi kelimpahan benih antar stasiun pengamatan. Dari seluruh kolektor lobster yang ditempatkan di lokasi penelitian, teridentifikasi dua lokasi yang memiliki kelimpahan benih lobster yang lebih tinggi di- bandingkan pada titik-titik pengamatan lainnya, yaitu berkisar antara 22-101 ekor/stasiun selama masa penelitian. Kedua lokasi tersebut berada di sekitar titik L3 dan L4 yang terletak di Desa Bumbang (Teluk Bumbang) dan di sekitar titik L8, L9, dan L10 yang berada di Desa Gerupuk (Teluk Gerupuk) seperti terlihat pada Gambar 1 dan Gambar 3.

Menurut Rios-Lara et al. (2007), habitat yang disukai oleh lobster umumnya terstruktur secara spasial; di mana lobster secara umum terdistribusi sekitar perairan dengan terumbu 
karang, namun kelimpahan yang lebih tinggi ditemukan berasosiasi dengan area yang strukturnya lebih kompleks di mana terdapat tempat-tempat tersembunyi untuk lobster. Perairan Teluk Bumbang dan Teluk Gerupuk ini berada di bagian dalam teluk yang relatif terlindung, dangkal, kekeruhan tinggi, dan dasar perairan pasir berlumpur. Karakteristik kedua lokasi tersebut ditunjukkan oleh data sebaran parameter kualitas air yang menunjukkan suhu dan TDS yang lebih tinggi jika dibandingkan bagian tengah perairan (Gambar 2). P. ornatus umumnya hidup pada habitat perairan yang relatif dangkal, terlindung, dasar berlumpur, dengan tingkat kekeruhan sedang hingga tinggi (Kemp \& Britz, 2008; Pitcher, 1993; Galil et al., 1989). Kelimpahan benih lobster alam pada kedua lokasi tersebut selain dipengaruhi oleh topografi perairan dan kondisi lingkungan perairan, juga sangat dipengaruhi oleh pergerakan arus dan gelombang. Arus yang terjadi di lokasi penelitian umumnya merupakan arus pasang surut yang pergerakannya dari Selatan ke Utara dan sebaliknya. Hasil pengamatan di lokasi penelitian, kisaran pasang surut yang terjadi dapat mencapai 3-4 m.

Berdasarkan hasil analisis klaster terhadap tingkat korelasi antar parameter kualitas air di setiap stasiun pengamatan, kawasan perairan Teluk Gerupuk dapat dikelompokkan menjadi empat klaster yang mewakili karak- teristik kualitas perairan tersebut (Gambar 4). Hasil analisis ini menunjukkan bahwa karakteristik perairan tersebut secara umum digambarkan oleh klaster 1 yang mencakup tujuh stasiun pengamatan yaitu stasiun L2, L3, L5, L7, L8, L9, dan L10. Pada seluruh stasiun yang termasuk ke dalam klaster 1 ini masingmasing ditemukan benih lobster dengan jumlah yang beragam, yaitu berkisar antara 2-86 ekor selama waktu pengamatan (Gambar 3). Klaster 2 diwakili oleh stasiun L1 (Gambar 4), di mana kondisi perairan relatif didominasi oleh ekosistem terumbu karang. Berdasarkan hasil pengamatan, pada stasiun 1 ditemukan benih lobster dalam jumlah yang relatif rendah yaitu 2 ekor/stasiun (Gambar 3). Klaster 3 diwakili oleh stasiun L4 (Gambar 4), yang berada tepat di dalam Teluk Bumbang dan merupakan titik di mana ditemukan jumlah benih lobster tertinggi selama waktu pengamatan yaitu mencapai 142 ekor (Gambar 3).

Klaster 4 yang diwakili oleh stasiun L6 (Gambar 4), yang berada di dekat mulut teluk memiliki karakteristik yang jauh berbeda dengan stasiun lainnya. Stasiun ini relatif dalam dan menghadap langsung ke laut terbuka, sehingga jauh dari pengaruh aktivitas terestrial dan lebih banyak mendapat pengaruh arus dan gelombang dari luar teluk (Gambar 1). Karakteristik stasiun L6 yang demikian menyebabkan benih lobster tidak dapat hidup pada lokasi tersebut, sehingga sama sekali

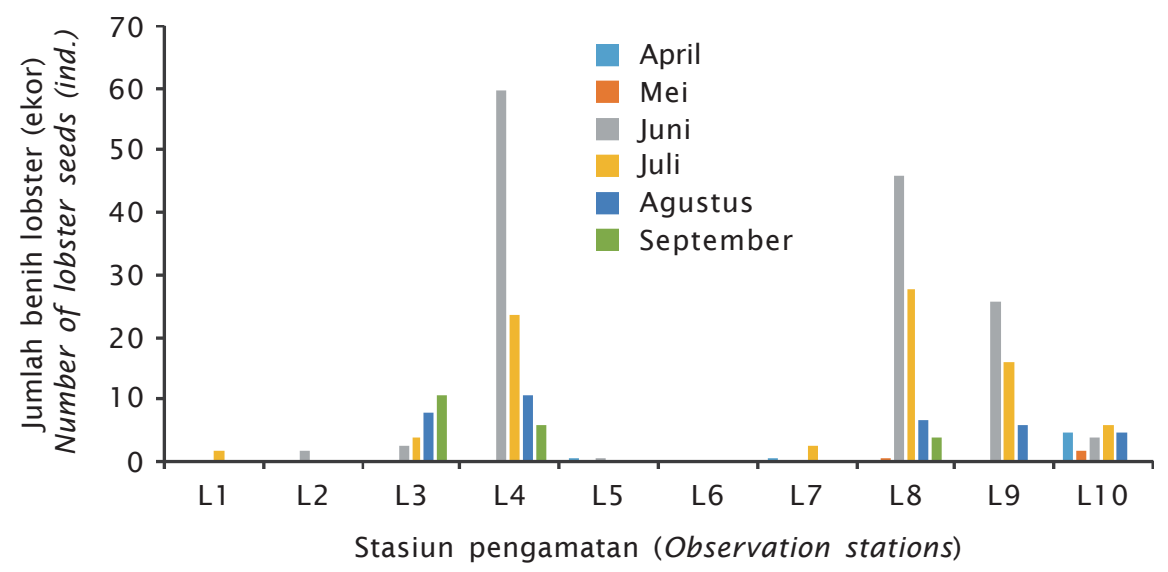

Gambar 3. Jumlah benih lobster Panulirus spp. yang diperoleh dari kolektor pada setiap stasiun pengamatan di perairan Teluk Gerupuk, Nusa Tenggara Barat

Figure 3. Number of lobster seed Panulirus spp. that collected from installed lobster collector at each observation stations in Gerupuk Bay, West Nusa Tenggara 
Dendogram: Single linkage, correlation coefficient distance

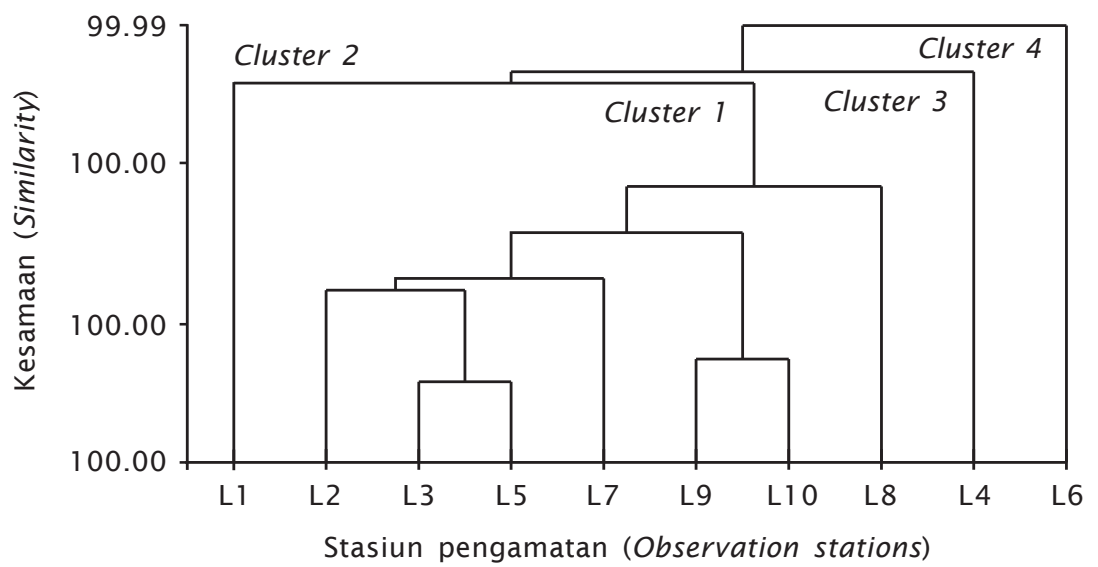

Gambar 4. Hasil analisis klaster dari parameter serapan karbon dan kualitas perairan

Figure 4. Cluster analysis result of carbon sequestration and water quality parameters

tidak ditemukan benih lobster yang menempel pada kolektor yang dipasang pada lokasi tersebut (Gambar 3).

P. ornatus hidup di perairan pantai yang dangkal dan keruh; kelimpahan lobster yang tinggi umumnya ditemukan di sekitar lokasi dengan arus yang tidak terlalu kuat (Galil et al., 1989; Rios-Lara et al., 2007). Selain itu, arus juga memengaruhi sebaran dari larva, karena diduga benih lobster yang tersebar dan berkembang pada suatu lokasi dapat berasal dari larva yang terbawa oleh arus dari lokasi yang berbeda; sedangkan pendapat lainnya menyatakan arus yang berlawanan dapat mengembalikan larva ke lokasi asalnya (RiosLara et al., 2007). Menurut Jones (2009), benih lobster yang ditangkap dari alam untuk kegiatan budidaya pembesaran umumnya adalah pada stadia yuwana berukuran $2-3 \mathrm{~cm}$. Telah diketahui juga bahwa distribusi spasial dan kelimpahan suatu spesies, salah satunya dipengaruhi oleh tren siklus hidup dari spesies itu sendiri (Rios-Lara et al., 2007). Puerulus merupakan stadia post larva yang bentuknya sudah menyerupai lobster dewasa, namun belum memiliki pigmen dan rangka luar yang keras (Suastika et al., 2008).

\section{Dinamika Temporal Kelimpahan Benih Lobster}

Berdasarkan pengaruh dinamika kualitas perairan di Teluk Gerupuk selama waktu pe- nelitian, pada bulan April-Mei kelimpahan benih lobster relatif rendah, dan mulai meningkat pada pertengahan bulan Juni. Kelimpahan benih lobster yang relatif tinggi ditemukan pada periode bulan Juni-Juli, yaitu berkisar 83-142 ekor/bulan, selanjutnya mengalami penurunan pada periode Agustus-September (Gambar 5). Tren kelimpahan benih lobster seperti ini di antaranya karena kecenderungan di perairan tersebut pada sekitar bulan Mei merupakan musim lobster muda (fingerling) yang berukuran sekitar $6-8 \mathrm{~cm}$; yang memungkinkan ketersediaan benih yuwana ukuran 2-3 cm (ukuran benih yang sering menempel pada kolektor) sekitar waktu tersebut relatif rendah (Gambar 5). Setelah bulan September kelimpahan benih mulai mengalami penurunan. Hal ini didukung oleh hasil kajian Suastika et al. (2008) bahwa di perairan Teluk Gerupuk sekitar bulan November merupakan musim di mana mulai banyak ditemukan lobster pada stadia puerulus.

Peningkatan kelimpahan benih lobster yang sangat mencolok terjadi pada bulan Juni dan Juli, di mana pada waktu tersebut diperkirakan sebagai pola rekrutmen temporal yang terjadi di perairan tersebut. Terbentuknya puncak kelimpahan benih lobster pada waktu tersebut masih belum diobservasi lebih dalam pada penelitian ini, namun menurut González \& Wehrtmann (2011), hal ini berhubungan erat dengan kondisi dan fenome- 


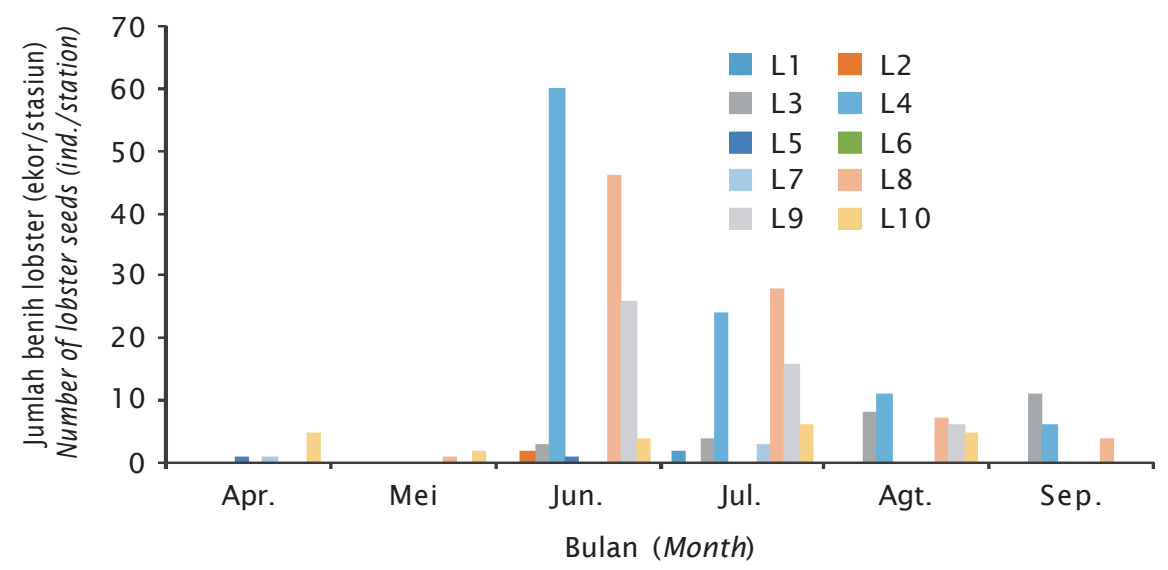

Gambar 5. Jumlah benih lobster Panulirus spp. yang diperoleh dari kolektor pada setiap waktu pengamatan di perairan Teluk Gerupuk, Nusa Tenggara Barat

Figure 5. Number of lobster seed Panulirus spp. that collected from installed lobster collector at each sampling time in Gerupuk Bay, West Nusa Tenggara

na oseanografi yang terjadi di sekitar lokasi penelitian. Pola rekrutmen ini sangat diperlukan sebagai dasar untuk memprediksi waktu penangkapan, dan strategi untuk pengelolaan populasi benih lobster alam (González \& Wehrtmann, 2011). Hal ini menjadi penting terkait aktivitas ekspor benih ke luar negeri dan suplai benih untuk budidaya di dalam negeri sendiri.

Analisis klaster berdasarkan korelasi parameter kualitas perairan Teluk Gerupuk dengan waktu pengamatan menunjukkan hasil bahwa perairan tersebut dikelompokkan ke dalam tiga klaster yang secara umum menggambarkan kondisi perairan berdasarkan waktu pengamatan (Gambar 6). Klaster 1 mewakili karakteristik perairan pada bulan Mei-Juni di mana pada selang waktu tersebut merupakan musim di mana benih lobster mulai muncul hingga mencapai puncak kelimpahan tertinggi pada bulan Juni. Klaster 2 mewakili karakteristik perairan pada bulan April, dan klaster 3 mewakili karakeristik perairan pada periode Juli-September. Karakteristik perairan pada klaster 2 (April) relatif berbeda dengan dua klaster lainnya. Pada waktu tersebut suhu perairan Teluk Gerupuk relatif tinggi dan konsentrasi oksigen terlarut relatif rendah, jika dibandingkan dengan klaster 1 dan 3 (MeiSeptember) (Gambar 2). Kondisi tersebut terkait juga dengan kelimpahan benih lobster relatif sangat rendah pada periode klaster 2 . Pada periode yang termasuk dalam klaster 3 , kondisi parameter kualitas perairan relatif sama, yaitu suhu perairan berada pada kondisi minimum yaitu berkisar antara $26,77^{\circ} \mathrm{C}-27,95^{\circ} \mathrm{C}$ (Gambar 2).

Berdasarkan hasil analisis klaster, kondisi kualitas perairan Teluk Gerupuk memperlihatkan perubahan secara temporal mulai dari periode April (klaster 2), Mei-Juni (klaster 1) hingga periode Juli-September (klaster 3 ). Secara umum, parameter kualitas perairan mengalami pergeseran antar klaster yang dapat memengaruhi pola rekrutmen benih lobster secara temporal. Menurut Vijayakumaran et al. (2014), lobster jenis Panulirus yang dikenal juga dengan spiny lobster biasanya menempati habitat dekat perairan pantai yang cenderung mengalami fluktuasi salinitas secara temporal. Pendederan larva $P$. homarus, $P$. ornatus, dan $P$. versicolor di laboratorium yang dilakukan Vijayakumaran et al. (2014) dengan salinitas berkisar antara $32-35 \mathrm{~g} / \mathrm{L}$, menunjukkan sintasan yang rendah ketika salinitas dinaikkan, namun menghasilkan sintasan yang bagus dan perkembangan normal ketika salinitas diturunkan hingga $28 \mathrm{~g} / \mathrm{L}$. Salinitas perairan di Teluk Gerupuk pada bulan April (klaster 2) berada pada titik terendah, sedangkan pada klaster 1 yaitu pada buIan Mei salinitas meningkat dan menurun kembali pada bulan Juni di mana ditemukan titik kelimpahan benih lobster tertinggi; selan- 
Dendogram: Single linkage, correlation coefficient distance

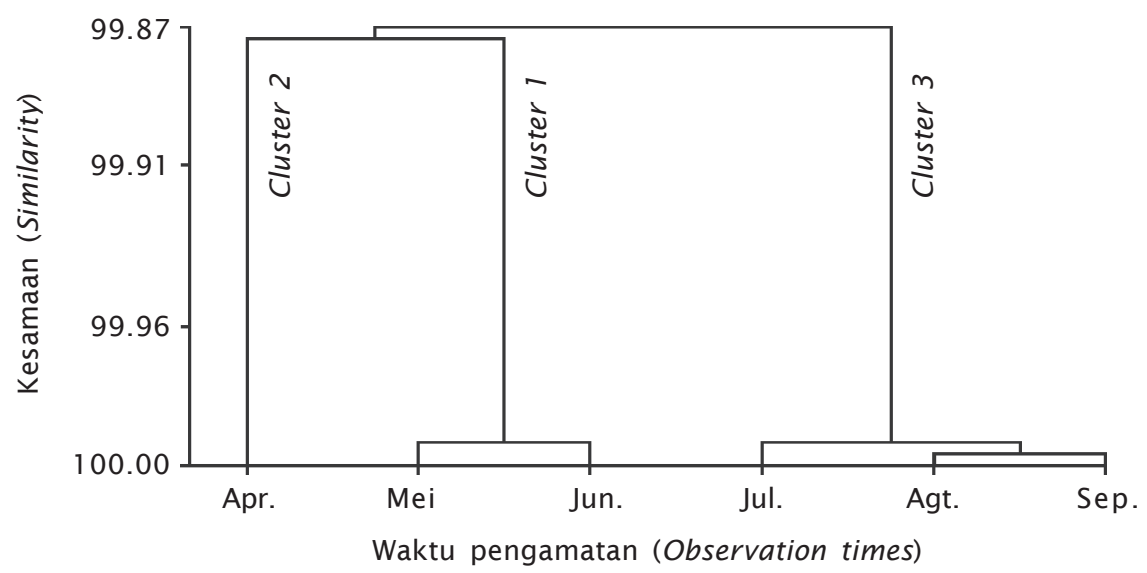

Gambar 6. Dendogram menunjukkan pengelompokkan kualitas perairan di Teluk Gerupuk, Nusa Tenggara Barat berdasarkan waktu pengamatan

Figure 6. Dendogram showing water quality clustering based on sampling periods in Gerupuk Bay, West Nusa Tenggara

jutnya pada klaster 3 salinitas mengalami peningkatan mulai dari bulan Juli hingga September. Secara umum kisaran fluktuasi salinitas di perairan Teluk Gerupuk tidak terlalu besar, namun kelimpahan benih lobster mengalami fluktuasi temporal yang cukup signifikan antar waktu pengamatan selama masa penelitian (Gambar 2 dan 5).

\section{Potensi Benih Lobster di Teluk Gerupuk untuk Mendukung Perkembangan Budi- daya Lobster}

Pengukuran kelimpahan benih lobster di suatu perairan secara mutlak masih jarang dilakukan, namun kelimpahan relatif dapat diestimasi dari data hasil tangkapan (Pitcher, 1993). Hasil tangkapan benih lobster di perairan Teluk Gerupuk pada tahun 2013 ditampilkan pada Gambar 7. Jumlah benih hasil tangkapan dari perairan Teluk Gerupuk berkisar antara 8.000-185.500 ekor/bulan (Gambar 7). Tren tangkapan benih lobster di perairan tersebut memperlihatkan kecenderungan yang hampir sama dengan tren kelimpahan benih lobster hasil pengamatan per bulan pada tahun yang sama khususnya pada periode April-September (Gambar 5 dan 7).

Benih lobster hasil tangkapan oleh masyarakat di sekitar perairan Teluk Gerupuk terdiri atas dua spesies yaitu: lobster pasir (Panulirus homarus) dan lobster mutiara ( $P$. ornatus) (Priambodo \& Jaya, 2009; Suastika et al., 2008; Priambodo \& Sarifin, 2008). Kedua spesies ini termasuk dua dari enam spesies lobster endemik di perairan Indonesia (Suastika et al., 2008). Ukuran benih lobster yang diperoleh selama pengamatan adalah berkisar antara 2-10 cm dengan ukuran rata-

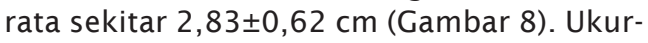
an benih lobster yang ditangkap oleh masyarakat di perairan Teluk Gerupuk relatif bervariasi, dan umumnya berada pada stadia yuwana yang berukuran sekitar $2-3 \mathrm{~cm}$; sedikit benih ukuran $6-8 \mathrm{~cm}$; dan benih puerulus yang secara visual masih terlihat transparan dengan ukuran sekitar <2 cm (Suastika et al., 2008; Priambodo \& Sarifin, 2008).

Permintaan pasar internasional yang tinggi terhadap lobster mendorong Indonesia untuk memacu produksi lobster melalui budidaya. Namun hingga saat ini, benih lobster hasil tangkapan khususnya dari perairan Teluk Gerupuk umumnya hanya dijual sebagai komoditas ekspor ke beberapa negara tujuan seperti Vietnam, Taiwan, Cina, dan Hongkong. Hal ini disebabkan karena harga benih lobster yang relatif mahal, yaitu pada awalnya berkisar Rp1 .500,00-Rp2.500,00/ekor untuk ukuran benih sekitar $2-3 \mathrm{~cm}$ (Suastika et al., 2008); kemudian terus meningkat hingga saat ini mencapai Rp12.000,00-Rp17.000,00/ ekor; sehingga dianggap sudah cukup menguntungkan bagi masyarakat yang berprofesi sebagai penangkap dan pengumpul be- 


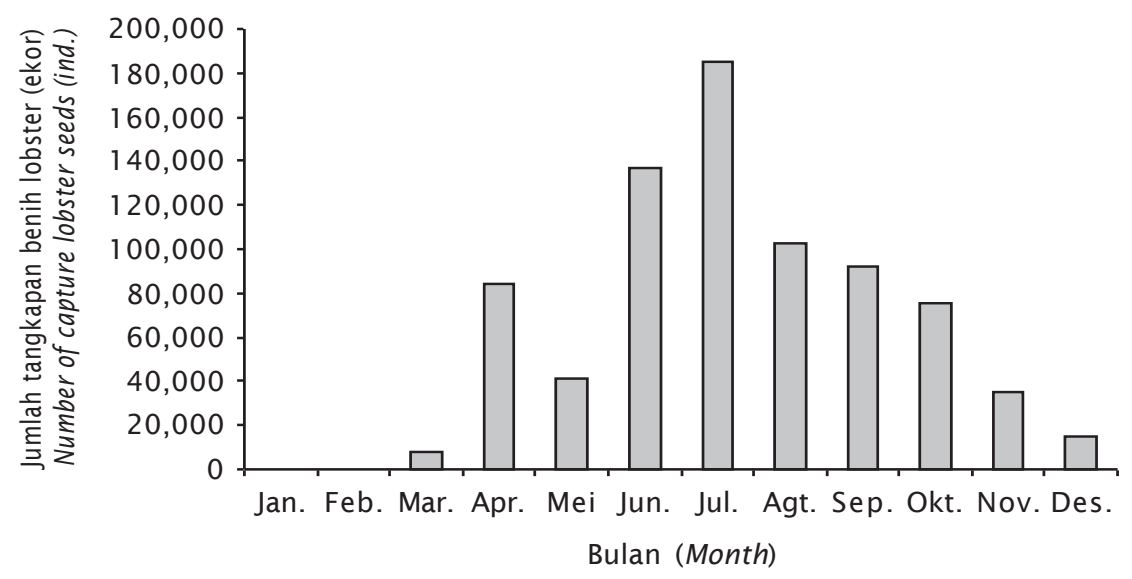

Gambar 7. Jumlah benih lobster Panulirus spp. hasil tangkapan dari perairan Teluk Gerupuk, Nusa Tenggara Barat

Figure 7. Number of lobster seed Panulirus spp. that catched from Gerupuk Bay, West Nusa Tenggara

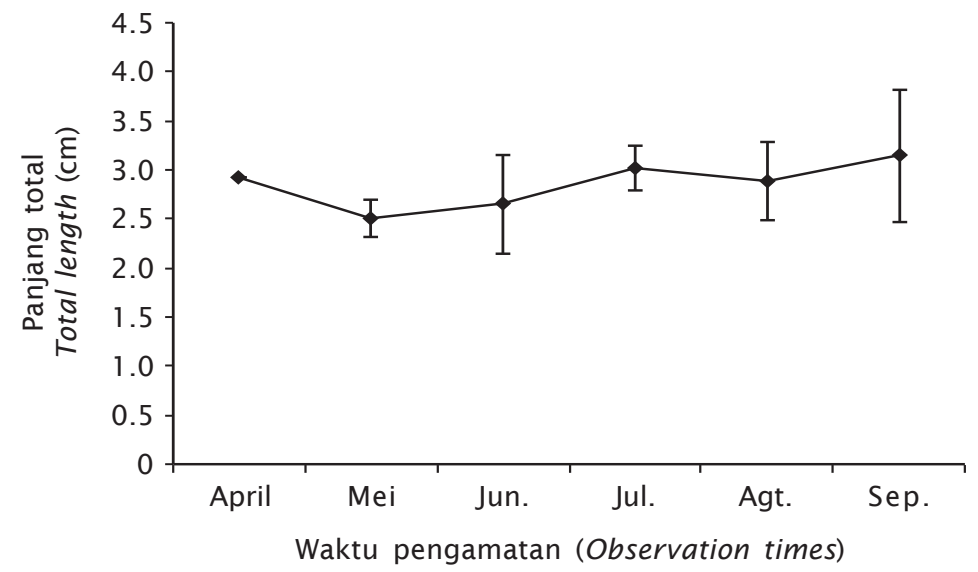

Gambar 8. Sebaran ukuran benih lobster Panulirus spp. hasil tangkapan dari perairan Teluk Gerupuk, Nusa Tenggara Barat

Figure 8. Size distribution of lobster seed Panulirus spp. that catched from Gerupuk Bay, West Nusa Tenggara

nih. Hal ini salah satunya disebabkan karena teknologi budidaya pembesaran lobster di Indonesia masih belum berkembang dengan baik. Di beberapa daerah, aktivitas budidaya pembesaran lobster sudah dilakukan oleh masyarakat, namun proses budidaya yang dilakukan umumnya masih secara konvensional sehingga tingkat keberhasilannya relatif masih rendah. Kendala yang dihadapi dalam budidaya pembesaran lobster yaitu belum adanya introduksi teknologi, sehingga tingkat sintasan lobster pada masa pendederan masih rendah, dan rentan terhadap serangan penyakit bakterial seperti milky haemolymph disease yang dapat menyebabkan kematian massal (Shield, 2011 ). Selain itu, hingga saat ini belum tersedia formulasi pakan lobster yang efisien dan ekonomis; masyarakat masih mengandalkan ikan rucah sebagai pakan utama. Dilaporkan bahwa makanan utama lobster Panulirus di perairan alami adalah jenis kekerangan; dan hasil studi yang menunjukkan bahwa konsumsi pakan pada lobster $\mathrm{Pa}$ nulirus dipengaruhi oleh suhu air, di mana 
konsumsi pakan meningkat dengan peningkatan suhu air (Kemp \& Britz, 2008). Rendahnya produktivitas budidaya pembesaran lobster dengan berbagai kendala yang dihadapi, semakin mendorong masyarakat untuk terus menjual hasil tangkapan benih dibandingkan melakukan budidaya pembesaran sampai ukuran konsumsi. Sementara itu, di negara tujuan ekspor seperti Vietnam teknologi pembesaran lobster sudah mulai berkembang (Jones, 2009); sehingga benih yang bersumber dari perairan Indonesia lebih banyak dibudidayakan dan memberikan keuntungan secara ekonomis bagi masyarakat di negara-negara pengimpor benih tersebut.

Besarnya potensi benih lobster yang tersedia di alam khususnya di perairan Teluk Gerupuk, semakin mendorong berkembangnya aktivitas penangkapan oleh masyarakat sekitar perairan tersebut. Aktivitas penangkapan benih yang semakin meningkat dan berlangsung untuk jangka panjang akan menyebabkan over eksploitasi yang akan berdampak negatif terhadap keberlanjutan sediaan populasi lobster di alam; ketersediaan benih akan semakin menurun bahkan habis, serta dapat menyebabkan terputusnya mata rantai dari siklus hidup lobster di alam, sehingga pada titik tertentu spesies lobster tersebut akan mengalami kelangkaan, bahkan punah.

Untuk membatasi dan mencegah terjadinya over ekploitasi terhadap populasi lobster di alam, diperlukan regulasi dari pemerintah untuk mengatur pengelolaan sumberdaya benih lobster dalam bentuk pembatasan aktivitas penangkapan dengan mengatur perizinan penangkapan lobster, pembatasan ukuran tangkapan, pembatasan kuota penjualan benih terutama untuk pasar ekspor, serta pembatasan ukuran benih yang diizinkan untuk diekspor. Hal ini bertujuan untuk menjaga sustainability ketersediaan benih untuk suplai budidaya, terutama di dalam negeri. Selain itu, juga dibutuhkan penekanan kebijakan untuk penyelenggaraan penelitian pengembangan teknologi pembenihan dan pembesaran lobster di Indonesia, karena sejauh ini belum ada kebijakan khusus dari pemerintah terkait pengembangan tekonologi budidaya lobster.

Ketersediaan teknologi pembenihan lobster diharapkan dapat mengurangi ketergantungan benih dari alam, dan juga bertujuan untuk pengkayaan stok alam sendiri. Ketersediaan benih yang berlimpah di alam dapat dikelola melalui teknologi budidaya pembesaran yang baik, sehingga dapat memberikan nilai tambah yang jauh lebih besar bagi perekonomian masyarakat pesisir dibandingkan hanya dengan penjualan benih hasil tangkapan. Selain itu, diharapkan Indonesia ke depannya dapat menjadi produsen lobster konsumsi dengan suplai benih lokal, sehingga biaya produksi lebih murah dengan kualitas dan harga yang dapat bersaing di pasar internasional.

\section{KESIMPULAN}

Kelimpahan benih lobster bervariasi baik secara spasial maupun temporal. Sebaran benih lobster tertinggi ditemukan pada lokasi yang terletak di bagian dalam teluk di sekitar Desa Gerupuk dan Desa Bumbang, di mana karakteristik perairannya relatif terlindung, dangkal, kekeruhan tinggi, dan dasar perairan pasir berlumpur. Secara temporal, puncak kelimpahan benih lobster tertinggi terjadi pada bulan Juni-Juli di mana data kelimpahan tersebut menunjukkan pola yang relatif sama dengan data total hasil tangkapan benih oleh masyarakat. Besarnya potensi benih lobster harus didukung dengan pengelolaan sumberdaya benih yang baik agar ketersediaan benih di alam tetap terjaga. Upaya yang dapat dilakukan oleh pemerintah untuk jangka pendek antara lain dengan mengatur perizinan penangkapan, pembatasan ukuran tangkapan, pembatasan kuota ekspor benih, serta pembatasan ukuran benih yang diizinkan untuk diekspor. Oleh karena itu, perlu dikembangkan teknologi budidaya lobster, baik pembenihan maupun pembesaran, sebagai langkah strategis dalam pengelolaan benih lobster alam, sehingga memberikan nilai ekonomis yang lebih tinggi bagi masyarakat pesisir, khususnya petani/penangkap lobster.

\section{UCAPAN TERIMA KASIH}

Terima kasih disampaikan kepada Balai Budidaya Laut Lombok atas bantuan selama pelaksanaan penelitian di lapangan. Penulis juga mengucapkan terima kasih kepada Buntaran, M.Si., Rusman, M.Si., Bapak Seme, dan teknisi dari Balai Budidaya Laut Lombok, yang telah membantu kelancaran penelitian di lapangan. Penelitian ini merupakan bagian dari penelitian Kajian Perubahan Iklim terhadap Perikanan Budidaya pada Pusat Penelitian dan Pengembangan Perikanan Budidaya Tahun Anggaran 2013. 


\section{DAFTAR ACUAN}

Arcenal, J.M.M. (2004). Sustainable farming of spiny lobster in Western Mindanao, Philippines. In Williams, K.C. Spiny lobster ecology and exploitation in the South China Sea region. Proceedings of a workshop held at the Institute of Oceanography. July 2004. Nha Trang. Vietnam, p. 19-20.

Caputi, N., Melville-Smith, R., de Lestang, S., Pearce, A., \& Feng, M. (2010). The effect of climate change on the western rock lobster (Panulirus cygnus) fishery of Western Australia. Can. J. Fish. Aquat. Sci., 67, 8596.

Galil, B., Pisanty, S., Spanier, E., \& Tom, M. (1989). The Indo-Pacific lobster Panulirus ornatus (Crustacea: Decapoda): a new Lessepsian migrant to the Eastern Mediterranean. Israel Journal of Zoology, 35, 241-243.

González, O., \& Wehrtmann, I.S. (2011). Postlarval settlement of spiny lobster, Panulirus argus (Latreille, 1804) (Decapoda: Palinuridae), at the Caribbean coast of Costa Rica. Lat. Am. J. Aquat. Res., 39(3), 575-583.

Effendi, H. 2003. Telaah Kualitas Air Bagi Pengelolaan Sumberdaya dan Lingkungan Perairan. Kanisius. Yogyakarta, $258 \mathrm{hlm}$.

Jeffs, A., \& Davis, M. (2003). An Assessment of the Aquaculture Potential of the Caibbean Spiny Lobster, Panulirus argus. GCFI [Gulf Caribbean Fisheries Institute], 54, 413-426.

Jones, C.M. (2009). Temperature and salinity tolerances of the tropical spiny lobster, Panulirus ornatus. Journal of The World Aquaculture Society, 40(6), 744-752.

Kemp, J.O.G., \& Britz, P.J. (2008). The effect of temperature on the growth, survival and food consumption of the east coast rock lobster Panulirus homarus rubellus. Aquaculture, 280, 227-231.

Phillips, B.F. (2006). Lobsters: biology, management, aquaculture, and fisheries. Blackwell Publishing Ltd., $506 \mathrm{pp}$.

Pitcher, C.R. (1993). Spiny lobster. In Wright, A. $\&$ Hill, L. (Eds.), Nearshore Marine Resources of the South Pacific. Information for Fisheries Development and Management. Pacific Islands Forum Fisheries Agency, p. 539607.

Priambodo, B., \& Jaya, I.B.M.S. (2009). Lobster aquaculture in Eastern Indonesia: Part I. methods evolve for fledgling industry. Global Aquaculture Advocate July/August, p. 36-39.
Priambodo, B., \& Sarifin. (2008). Lobster aquaculture industry in Eastern Indonesia: present status and prospects. In William, K.C. Spiny lobster aquaculture in the AsiaPacific region. Proceedings of an International Symposium. Nha Trang, 9-10 December 2008. Vietnam, p. 36-45.

Radiarta, I N., \& Rasidi. (2012). Analisa spasial kondisi kualitas perairan untuk mendukung budidaya rumput laut di Teluk Gerupuk Kabupaten Lombok Tengah Provinsi Nusa Tenggara Barat. Prosiding Seminar Nasional Perikanan Indonesia 2012. Sekolah Tinggi Perikanan Jakarta.

Radiarta, I N., Erlania, \& Rusman. (2013). Pengaruh iklim terhadap musim tanam rumput laut, Kappaphycus alvarezii, di Teluk Gerupuk Kabupaten Lombok Tengah, Nusa Tenggara Barat. J. Ris. Akuakultur, 8(3), 453-464.

Rios-Lara, V., Salas, S., Javier, B.P., \& Irene-Ayora, P. (2007). Distribution patterns of spiny lobster (Panulirus argus) at Alacranes reef, Yucatan: Spatial analysis and inference of preferential habitat. Fisheries Research, 87, 35-45.

Shield, J.D. (201 1). Diseases of spiny lobsters: A review. Journal of Invertebrate Pathology, 106, 79-91.

Suastika, M., Sukadi, F., \& Surahman, A. (2008). Studi kelayakan: Meningkatkan pembesaran dan nutrisi lobster di Nusa Tenggara Barat. In Jones, C. (Ed.). ACIAR - Smallholder Agribusiness Development Initiative (SADI) Report, $23 \mathrm{hlm}$.

Thangaraja, R., \& Radhakrishnan, E.V. (2012). Fishery and ecology of the spiny lobster Panulirus homarus (Linnaeus, 1758) at Khadiyapatanam in the southwest coast of India. J. Mar. Biol. Ass. India, 54(2), 69-79.

Thao, N.T.K. (2012). Opportunities and challenges in lobster marine aquaculture in Viet Nam: The case of Nha Trang Bay. Thesis. The Norwegian College of Fishery Science University of Tromso, Norway \& Nha Trang University. Vietnam, $66 \mathrm{pp}$.

Vijayakumaran, M., Maharajan, A., Rajalakshmi, S., Jayagopal, P., \& Remani, M.C. (2014). Early larval stages of the spiny lobsters, Panulirus homarus, Panulirus versicolor and Panulirus ornatus cultured under laboratory conditions. International Journal of Development Research, 4(2), 377-383. 